\title{
A Study on Patients with Suspected Schwannoma of the Neck
}

\author{
Yojiro Kawamura ${ }^{1)}$, Toshikazu Shimane ${ }^{12)}$, Taisuke Nakamura ${ }^{1)}$, \\ Yuko Shimotatara $^{1)}$, Yoichi Ikenoya ${ }^{1)}$, Yukiomi Kushihashi ${ }^{3)}$, \\ Naokazu Fujii ${ }^{1)}$ and Sei Kobayashi ${ }^{1)}$
}

In this study, we examined the possibility of definitive diagnosis of schwannoma prior to surgery in patients admitted to our hospital between April 2009 and December 2013. There were 37 cases of suspected schwannoma, of which 11 cases were finally diagnosed as not having schwannoma. Of these 11, 5 cases were diagnosed preoperatively as not having schwannoma and 5 were diagnosed intraoperatively as not having a schwannoma; in the remaining 1 case, the diagnosis was made postoperatively. The results revealed determination of the following as important for the differential diagnosis: clinical course (rate of growth of the tumor), tumor mobility (pain and hardness), MRI findings (tumor location and shape, and presence/absence of contrast enhancement), ultrasound findings (tumor blood vessel distribution), and findings on fine-needle aspiration cytology. If all of these fundamental findings are reconfirmed during the initial examination of referred patients, we believe that a definitive diagnosis may be made in many cases.

Keywords : schwannoma, diagnosis, cervical tumor

\section{References}

1) Shimane T, Ikeda K, Kawaguchi K, et al. : A clinical study on cervical tumors initially suspected of Schwannomas. Pract Otol (Kyoto) 106: 51-59, 2013.

2）鴆根俊和，徳留卓俊，下鑪裕子，他：頸部に発生した上喉 頭神経鞘腫の 1 例. 頭頸部外 23: 87-91, 2013.

3）嶋根俊和, 下鑪裕子, 中村泰介, 他: 頸部神経鞘腫手術症 例の検討. 頭頸部外 23: 419-423, 2013.

4) 古川まどか, 古川政樹, 久保田彰, 他 : 頸部神経鞘腫の取 り扱い. 頭頸部外 17: 105-112, 2007.

5) 坂尾寿彦, 野口志郎, 村上信夫, 他：頸部神経鞘腫 35 例 の検討. 日外会誌 91: 407-410, 1990.

6) 平出文久, 西澤伸志 : 神経系頸部腫瘤. 耳鼻 - 頭頸部外科 MOOK 2: 122-133, 1986.

7) 嶋根俊和, 池田賢一郎, 江川峻哉, 他 : 当科における頸部 神経鞘腫の検討. 頭頸部外 20: 261-265, 2010.

8) de Araujo CE, Ramos DM, Moyses RA, et al. : Neck nerve trunks schwannomas: clinical features and postoperative neurologic outcome. Laryngoscope 118: 1579-1582, 2008.

9）古川政樹：頸部の超音波検査法. JOHNS 9: 1665-1672,

1) Department of Otorhinolaryngology, Showa University, Fujigaoka Hospital

2) Department of Dentistry and Oral Surgery, Showa University Hospital

3) Department of Otorhinolaryngology, Odawara Municipal Hospital
1993.

10) Haraguchi $\mathrm{H}$ and Okuno $\mathrm{H}$ : Neurilemmoma of the cervical vagus nerve; a case report. Pract Otol (Kyoto) 89: 229-235, 1996.

11) Takagi N, Fukushima $T$ and Murakami $M$ : Pre-operative diagnosis of neurinoma in the head and neck region. Pract Otol (Kyoto) 94: 1111-1116, 2001.

12) 門田哲弥, 森 智昭, 小野智裕, 他: 頸部副神経鞘腫の 1 例. 耳鼻展望 52: 91-95, 2009.

13) 門田哲弥, 古矢彩子, 嶋根俊和, 他: 頸部舌神経鞘腫の 1 例. 耳鼻展望 51: 232-236, 2008.

14) Bailey $H$ : The clinical aspects of branchial cysts. Br J Surg 10: 565-572, 1922

15) Maran AG and Buchanan DR : Branchial cysts, sinuses and fistulae. Clin Otolaryngol Allied Sci 3: 77-92, 1978.

16) Som PM, Biller HF, Lawson W, et al. : Parapharyngeal space masses: an updated protocol based upon 104 cases. Radiology 153: 149-156, 1984

17）菊池康隆, 矢部 武, 関 哲郎, 他 : 副咽頭間隙に生じた 稀な先天性側頸囊胞の 2 症例. 口腔咽頭科 5: 98, 1992.

Corresponding Author Address : Yojiro Kawamura kawamura_1984@yahoo.co.jp 
18）小形哲也, 山本悦生, 大村正樹, 他 : 副咽頭間隙鰓性囊胞 の 1 症例. 耳鼻臨床 補 74: 57-58, 1994.

19) Yoshitake H, Ikarashi T, Nasu T, et al. : A case of a branchial cyst in the parapharyngeal space. Pract Otol (Kyoto) 91: 285290, 1998. 